\title{
Restitution Penalty Enforcement in Human Trafficking Criminal Cases
}

\author{
David Panahatan Pardede \\ \{pardede_david@yahoo.com\} \\ Doctor of Law, Universitas Jayabaya, Jakarta, Indonesia
}

\begin{abstract}
The implementation of restitution provided for victims of human trafficking still could not give the victims their rights. Most of them had no idea about restitution rights, even if they know about it, their requests for restitution were often rejected in the trial. In the Criminal Procedure Code, defendants' rights are above the rights of witnesses and victims. Hence, in every "due process", defendants have to be able to defend himself. As the result, victims and witnesses will be less-prioritized. This research employed normative legal method to obtain secondary data in the forms of primary, secondary and tertiary legal materials. Primary data supported the secondary data. It is found forced asset confiscation from the defendants of human trafficking can proceed starting from the investigation process. The confiscation can only be carried out by an investigator after obtaining a permit from the Chairman of the local District Court. However, in urgent situations, investigators may act on their own when it is not possible to obtain a permit in advance. After the asset confiscation is carried out, investigators are obliged to report to the Head of the District Court to obtain approval for the confiscation process. The legal basis for the confiscation is Article 1 point 16 of the Criminal Procedure Code, which states that confiscation is an act done by investigators to take over and or keep under control all movable or immovable, tangible or intangible objects as means of proof in investigation, prosecution and trial. When evidences have been collected, confiscation is the follow-up action to the investigation process.
\end{abstract}

Keywords: Forced Attempt, Restitution, Human Trafficking Crime

\section{Introduction}

From a victimological perspective, restitution is related to repairing or restoring physical, moral, and property losses, the victim's position, and the victim's rights for the damage that is afflicted upon them by the criminal offender [1]. It is a form of accountability for the criminal and attempts to rectify their actions. Meanwhile, from the victimology perspective, compensation is related to contributing some form of balancing force to empower the victim in mitigating a malicious act that befell upon them. Such event causes physical, morale, and property damage. Therefore, victims are entitled to receive compensation for the suffering they have experienced.

Restitution can be returning something to the rightful owner, an attempt to repair losses, giving compensation for damage, or restoring something to its original condition [2]. The restitution rights are stated in Article 7A (1) of Th Law Number 31 of 2014 concerning Amendments to Law Number 12 of 2006 concerning Protection of Witnesses and Victims [3]. Restitution in Law of Eradication of Crime Against Human Trafficking (Undang-undang Pemberantasan Tindak Pidana Perdagangan Orang-UUPTPPO) includes restoring the loss of 
wealth or income, repairing the suffering inflicted upon them, coverage of fees for medical and/or psychological treatment and/or other losses suffered by the victim of human trafficking [4]. Other losses include loss of property, basic transportation costs, attorney's fees or other costs related to legal proceedings, or loss of income promised by the perpetrator [5].

Although the law has stipulated restitution for victims of human trafficking, the reality is that this right is inaccessible for the victims [6]. It is speculated that the reason for such inconvenience is that the victim does not know such right exists or does not possess an in-depth understanding of it. Even if it is fully socialized, the demands for restitution are rejected when it comes to trial. In the Criminal Procedure Code, defendants' rights are always above the rights of witnesses and victims. The defendant is always placed in the final process in every "due process." It enables them to defend themselves but marginalizes the place in terms of attention for victims and witnesses.

Victims have an important role in revealing the truth about what they experienced in a crime, either directly or indirectly, because their stories play a crucial role in determining the existence of a crime. The view that the victim is sufficiently positioned as a witness in a criminal act is inappropriate. This is because this will result in the victim being discriminated against in the criminal law. They are in the most disadvantaged position when a crime has occurred. Therefore, the thought that the orientation of criminal law, which initially focused on the perpetrator of the criminal act, must change by also considering the victim's condition of a crime. The state should take responsibility for its contribution to the occurrence of a criminal act due to its discriminatory statutory regulations and poor law enforcement to simply not provictims.

Thus, providing compensation or restitution can demonstrate the responsibility of the state. Financial compensation, such as goods or money, to victims, is one of the oldest forms of restitution within the criminal system known in the history of human civilization [7]. In the Criminal Code, the provisions governing compensation are reflected in Article $14 \mathrm{C}$. It states that when a judge imposes a conditional sentence, the judge can stipulate a special requirement for the offender to give full or partial compensation to the victim. Such a compensation scheme is applicable as an addition to the general requirement.

When it comes to claiming compensation, it can be pursued to merge the cases. The right to demand compensation for the injured party is regulated in the Criminal Procedure Code akin to the civil compensation system found in Article 98 to Article 101 of the Criminal Procedure Code.

\section{Research Methods}

The method used in this research is normative legal research conducted to obtain secondary data consisting of primary legal materials, secondary legal materials, and tertiary legal materials. The use of primary data is for additional material for legal material secondary data.

\section{Results and Discussion}

Indonesia as a Constitutional state seeks to provide legal protection to all its citizens by protecting human rights. When someone experiences a violation of the law, the state should implement and enforce the law to provide a sense of justice for the victim. Legal protection for 
all citizens is a universal concept, and every country has its way of realizing legal protection for its citizens.

One of the legal efforts to protect citizens who are victims of criminal acts happened in the justice system. Victims of crimes in the national legal system often do not receive serious attention. It can be seen from the lack of granting rights for victims of crime regulated in statutory provisions. The victim of a criminal act is the party, who is in a disadvantaged position, exposed to prolonged suffering because of the trauma they have experienced. Victims often do not receive as much protection as provided by law compared to perpetrators of crimes. Consequently, even though the perpetrator of the crime has been sentenced to criminal sanctions by the court, the victim's condition is still neglected, and their rights are not fulfilled.

Efforts to restore the condition of victims of human trafficking can be provided by legal protection relating to the victims' rights [8]. In the Declaration of Basic Principles of Justice for Victims of Crimes and Abuse of Power in 1985, it is stated that victims' rights comprise entitlement to compensation, restitution, rehabilitation, and reintegration for victims of trafficking. The state gives compensation to victims of the crime of trafficking if the perpetrator does not fulfill the obligation of restitution to the victim. The state is obliged to seek financial compensation for victims if the perpetrator is unable to do so. The provision of compensation by the government is an effort to develop a sense of truth and justice for victims.

Victims are hopeful that Eradication of Crime Against Human Trafficking Law Number 21 of 2007 can provide justice claiming their rights. The rights of victims are protected under Article 43 to Article 47. In addition, such law contains elements and systems of legal protection for victims by providing compensation, restitution, repatriation, and rehabilitation for victims. The perpetrator of the criminal act should provide compensation due to a criminal act committed against another person in terms of granting restitution rights for victims of criminal acts [9]. However, concerning a criminal act against the law but does not violate the rights of a person and therefore does not cause real harm, imprisonment is sufficient for the perpetrator. Otherwise, it is appropriate to complement the penalty with compensation for the victim [10].

The regulation on providing restitution for victims of trafficking aims to create a balancing force between the perpetrator and the victim. Victims have the right to receive equal treatment and attention in the trial process. Perpetrators receive sanctions in the form of penalties to demonstrate that sanction means everyone is equal in the eyes of the law when a crime has been committed. On the other hand, victims will receive protection for their rights of restitution by the perpetrator. The application of equality in law is a consequence of respect and protection of human rights and under Aristotle's distributive justice.

Regarding the implementation of restitution punishment, the current system is unproductive. As previously explained, several court decisions regarding trafficking cases do not grant restitution for the victim. Even if submitted, the claim is rejected based on the lack of submission from the victim. Even if a claim for restitution has been filed since the investigation process, the victim must be able to provide clear evidence, both in the form of receipts for the expenditures or proof of damage of lost assets to the public prosecutor. Based on this evidence, the public prosecutor will then request the court to sanction restitution.

Law enforcement must implement these laws and regulations using their intellectual and spiritual intelligence to achieve justice for victims. The existing law must side with humans because it is made to fulfil a sense of justice for humans. If in various decisions during the criminal case of trafficking, there is often an impasse in the implementation of restitution, and the use of distributive justice can assist law enforcers in making decisions to impose appropriate sanctions for the perpetrators. 
In essence, efforts to obtain restitution for victims of trafficking in persons can be carried out through preventive-, repressive- and restorative measures. The government has enacted preventive action by issuing various laws and regulations to ensure that victims receive compensation through restitution. The researcher offers the concept of compensation through penal mediation at the beginning of the investigation. In such a moment, restorative action can also be implemented through forced confiscation of the perpetrator's assets to benefit from the trafficking. Although it is challenging to attempt to force confiscation of the assets, the procedural steps to confiscate the assets must relentlessly endeavour. It can start from tracking assets, freezing savings accounts, and confiscating existing assets. These are the early phase to get restitution. The confiscation of assets by the government sends a cautionary message to the public regarding their commitment to combat human trafficking and that the victims are the most prioritized for legal protection.

If the perpetrators often ignore the criminal fines, then the forced confiscation of assets will exploit a deterrent effect for the perpetrators and the public. Perpetrators of the criminal act of trafficking will be fearful if their assets gained from the crime are confiscated by the state without having to go through criminal justice first. Repressive measures are intended for victims to receive compensation [11]. While the repressive measures to gain closure in a criminal trafficking case, researchers have reconstructed the imposition of substitute imprisonment, initially only for 1 year to one-third of the basic crimes stipulated Eradication of Crime Against Human Trafficking law. If the punishment theory mentions retaliation theory, relative theory, or a combined theory in imposing criminal sanctions, the researcher chooses punishment, which is distributive justice in nature.

Restitution for victims can achieve peaceful resolution when they encounter legal problems peacefully and satisfaction for both victims, perpetrators, and the community because the law is dedicated to demonstrating legal certainty and justice. Allowing victims access to restitution that will benefit them of compensation is a step forward in providing legal protection and law enforcement in Indonesia. This, of course, has a positive impact on the Indonesian criminal justice system because it allows for not only legal protection for suspects or defendants as mandated by the Criminal Code but also provides legal protection for victims as mandated in the Eradication of Crime Against Human Trafficking Law and the Witness and Victim Protection Act.

\section{Conclusion}

Confiscation of assets of the perpetrators gained from human trafficking criminal activities must be considered at the beginning of the investigation process. An investigator can only execute the confiscation of assets in criminal law if a permit is obtained from the Chairman of the local District Court. However, in an urgent situation, the investigator can proactively act as if it is not possible to obtain a permit in advance. After the confiscation, the investigator must report to the Head of the District Court to obtain approval for the confiscation process.

The legal basis for the confiscation is entailed in Article 1 point 16 of the Criminal Procedure Code, which states that seizure is a series of actions by an investigator to take over and or control movable or immovable, tangible, or intangible objects for proof in the investigation, prosecution, and trial. After the evidence is found during the confiscation process, the investigation process can proceed. 


\section{References}

[1] Adiastari, Cindy, and Hartiwiningsih Hartiwiningsih, 'Legal Protection of Child Trafficking in the Provision of Compensation and Restitution Rights in Indonesia', International Journal of Multicultural and Multireligious Understanding, $5.2 \quad$ (2018) <https://doi.org/10.18415/ijmmu.v5i2.424>

[2] Ali, Mahrus, and Ari Wibowo, 'Kompensasi Dan Restitusi Yang Berorientasi Pada Korban Tindak Pidana', Yuridika, 33.2 (2018)<Https://Doi.Org/10.20473/Ydk.V33i2.7414>

[3] Bawono, Bambang Tri, 'Restitution Rights As A Construction Of Justice Referring To The Law On Protection Of Witnesses And Victims', International Journal Of Law Reconstruction, 5.1 (2021) <Https://Doi.Org/10.26532/Ijlr.V5i1.15321>

[4] Daly, Kathleen, And Gitana Proietti-Scifoni, 'Reparation And Restoration', In The Oxford Handbook Of Crime And Criminal $\quad$ Justice, 2012 <Https://Doi.Org/10.1093/Oxfordhb/9780195395082.013.0008>

[5] Maculan, Elena, And Alicia Gil Gil, 'The Rationale And Purposes Of Criminal Law And Punishment In Transitional Contexts', Oxford Journal Of Legal Studies, 40.1 (2020) <Https://Doi.Org/10.1093/Ojls/Gqz033>

[6] Novika, Giofanni Dian, 'Legal Protection In Restitution To The Victims Of Human Trafficking', Legality: Jurnal Ilmiah Hukum, 28.1 (2020) < Https://Doi.Org/10.22219/Ljih.V28i1.10374>

[7] Nuraeny, Henny, 'Trafficking Of Migrant Workers In Indonesia: A Legal Enforcement And Economic Perspective Of Prevention And Protection Efforts', European Research Studies Journal, $2017<$ Https://Doi.Org/10.35808/Ersj/871>

[8] Putri, Miszuarty, 'Pelaksanaan Restitusi Bagi Anak Yang Menjadi Korban Tindak Pidana Sebagai Bentuk Pembaruan Hukum Pidana Berdasarkan Peraturan Pemerintah Nomor 43 Tahun 2017', Soumatera Law Review, 2.1 (2019) <Https://Doi.Org/10.22216/Soumlaw.V2i1.3567>

[9] Wantu, Fence M, And Mohamad Taufiq Zulfikar Sarson, 'Legal Protection Of Women As Victim Of Domestic Violence', Indonesian Journal Of Advocacy And Legal Services, 1.2 (2020) <https://doi.org/10.15294/ijals.v1i2.36093> 